Тищук I. В., к.е.н., доцент

Поліщук Л. М., к.т.н., доцент

Луцьький національний технічний університет

м. Луиььк, Украӥна

DOI: https://doi.org/10.30525/978-9934-26-028-5-40

\title{
СОЦАЛЬНИЙ ТУРИЗМ В СИСТЕМІ РЕГІОНАЛЬНОГО ТУРИСТИЧНОГО РИНКУ
}

Сьогодні як стверджують фахівці туристичної галузі, туристична сфера як в Україні так і в усьому світі зазнає збитків внаслідок ситуації яка склалася щодо проведення заходів протидії пандемії COVID-19.

На офіційному сайті «Радіо свобода» зазначено, що «через пандемію COVID-19 українці дуже обмежені у виборі літнього відпочинку. Так, за даними туроператорів та українського МЗС, наразі охоче впускають українських туристів лише кілька країн, та й ті відкрили свої кордони лише 3 липня. Передовсім це Туреччина, Сгипет, Туніс, Албанія та Хорватія, та ще деякі держави, які не вважаються найбільш популярними напрямками літнього відпочинку» [1].

В Україні під час пандемії COVID-19 особливе значення відводиться саме соціальному туризму, оскільки через складну ситуацію українці дуже обмежені у виборі відпочинку а також не маючи фінансової можливості через складне матеріальне становище.

Науковці стверджують, що така ситуація $є$ позитивною для розвитку внутрішнього туризму і такі види туризму як спортивний, зелений (сільський), екологічний, молодіжно студентський, туризм людей похилого віку (туризму «сеньйорів») мають перспективи для розвитку. Які саме за мотиваційною ознакою відносяться до соціального туризму.

У матеріалах Александрова С.А., Сова А.Р. зазначено, що «значення туризму важко переоцінити. Він $є$ важливою сферою економіки багатьох країн світу, відіграє певну роль у підвищенні 
інвестиційної привабливості регіонів, вирішенні соціальних проблем, створенні нових робочих місць, підвищенні добробуту населення країни» [2].

Згідно даних офіційного сайту статистики України, значна кількість українців немає фінансової можливості на якісний, доступний відпочинок так і на профілактичне лікування, що в свою чергу потребує активізувати розвиток саме соціального туризму.

Науковець Колотуха О.В. у своїх дослідження подає таке визначення «Соціальний туризм - це туризм, який повністю або частково здійснюється за рахунок бюджетних коштів, коштів державних позабюджетних фондів, а також коштів роботодавців» [3].

Задорожна К.І. вважає, що в якості пріоритетних видів соціального туризму зазначає: дитячо-юнацький, самодіяльний (спортивно-оздоровчий), лікувально-оздоровчий, екологічний, культурно-пізнавальний, сімейні подорожі, туризм для молоді та ветеранів, для інвалідів тощо [4].

У Законі України «Про туризм» про соціальний туризм, як окремий вид туризму не згадується, лише у Розділ II державна політика та державне регулювання в галузі туризму, у статті 6. Основні способи та цілі державного регулювання в галузі туризму. Основні пріоритетні напрями державної політики в галузі туризму, зазначено: «забезпечення доступності туризму та екскурсійних відвідувань для дітей, молоді, людей похилого віку, осіб 3 інвалідністю та малозабезпечених громадян шляхом запровадження пільг стосовно цих категорій осіб» [5].

Згідно проведеного аналізу багатьох наукових праць дослідників, які спеціалізуються саме на дослідженні соціального туризму, нами було сформовано чітку сегментацію соціального туризму станом на сьогодні, яка подана в таблиці 1.

У Монреальській декларації, прийнятої у 1996 році Генеральною асамблеєю IBST, зазначається, що «соціальний туризм має забезпечувати доступність туристичного відпочинку для всіх, включаючи сім’і, молодь та літніх людей» [6]. 


\section{Сегментація соціального туризму}

\begin{tabular}{|c|c|c|}
\hline Вид туризму & Характеристика & Значення \\
\hline $\begin{array}{l}\text { Дитячо- } \\
\text { юнацький } \\
\text { туризм }\end{array}$ & \begin{tabular}{|} 
Орієнтований на соціально важливу \\
категорію нашого суспільства - \\
підростаюче покоління - посідає \\
особливе місце в системі \\
рекреаційно-туристської діяльності
\end{tabular} & $\begin{array}{c}\text { При розумній організації } \\
\text { дитячо-юнацький туризм } \\
\text { може дати відчутний } \\
\text { економічний ефект }\end{array}$ \\
\hline $\begin{array}{l}\text { Молодіжно- } \\
\text { студентський } \\
\text { туризм }\end{array}$ & $\begin{array}{c}\text { Орієнтований на студентську } \\
\text { молодь через розвиток туристичних } \\
\text { центрів, різного роду гуртків, } \\
\text { краєзнавства }\end{array}$ & $\begin{array}{c}\text { В розвинених країнах } \\
\text { світу успішно діє система } \\
\text { дешевих студентських } \\
\text { закладів розміщення - } \\
\text { хостелів - яка в Україні } \\
\text { тільки формуєтья }\end{array}$ \\
\hline $\begin{array}{c}\text { Туризм } \\
\text { людей } \\
\text { похилого } \\
\text { віку } \\
\text { (туризму } \\
\text { «сеньйорів») } \\
\end{array}$ & $\begin{array}{c}\text { У високорозвинених країнах } \\
\text { подорожі людей похилого віку є } \\
\text { масовими і надзвичайно } \\
\text { популярними і конкурують } 3 \\
\text { молодіжними подорожами }\end{array}$ & $\begin{array}{c}\text { В свою чергу буде } \\
\text { розвиватись туристична } \\
\text { інфраструктура }\end{array}$ \\
\hline $\begin{array}{c}\text { Спортивний } \\
\text { туризм }\end{array}$ & $\begin{array}{c}\text { Головна особливість спортивного } \\
\text { туризму полягає в тому, що він, не } \\
\text { потребує відносно великих } \\
\text { матеріальних видатків, так як, } \\
\text { по-перше, розвивається в } \\
\text { існуючому навколишньому } \\
\text { природному середовищі і не } \\
\text { вимагає значних капіталовкладень } \\
\text { для підготовки та проведення } \\
\text { туристсько-спортивних масових } \\
\text { заходів та зведення спеціальних } \\
\text { споруд для їх проведення }\end{array}$ & $\begin{array}{c}\text { Не потребує великих } \\
\text { капіталовкладень, але } \\
\text { впливає на розвиток } \\
\text { масового туризму, } \\
\text { шляхом забезпечення } \\
\text { проведення самих заходів } \\
\text { силами туристів, що } є \\
\text { економічно вигідним для } \\
\text { регіону }\end{array}$ \\
\hline $\begin{array}{l}\text { Зелений } \\
\text { (сільський) } \\
\text { туризм }\end{array}$ & \begin{tabular}{|c|} 
Зелений (сільський) туризм в \\
Україні знаходиться на стадії \\
формування. Віднесення його до \\
категорії соціального $є$ дещо \\
парадоксальним, адже це, як \\
правило, відбувається за фактом \\
кінцевого споживання турпродукту \\
\end{tabular} & $\begin{array}{c}\text { Розвиває місцеву } \\
\text { економіку, сприяє } \\
\text { підвищенню зайнятості } \\
\text { населення, створенню } \\
\text { нових робочих місць на } \\
\text { селі, відроджуються } \\
\text { народні промисли } \\
\end{array}$ \\
\hline $\begin{array}{c}\text { Екологічний } \\
\text { туризм }\end{array}$ & \begin{tabular}{|c|} 
Орієнтований на розвиток \\
територій національних природних \\
та регіональних ландшафтних \\
парків, заповідних територій 3 \\
метою збереження природного \\
середовища
\end{tabular} & $\begin{array}{c}\text { Сприятиме створенню } \\
\text { освітніх екологічних } \\
\text { програм для широкого } \\
\text { загалу населення, роз- } \\
\text { робці туристських мар- } \\
\text { шрутів для організованих } \\
\text { туристських груп } \\
\end{array}$ \\
\hline
\end{tabular}


Схожа думка прослідковується і у роботі Дж. Хокленда: «Концепція «соціального туризму» має на увазі, що «всі громадяни, незалежно від економічного стану або соціального статусу, повинні мати можливість поїхати у відпустку» [7].

Соціальний туризм - одне з основних суспільно-економічних умов розвитку туризму. Він має особливе значення для розбудови сучасної туристичної України.

Станом на сьогодні, у зв'язку з проведенням заходів протидії пандемії COVID-19, приватизації, інфляція, економічної кризи, призвели до різкого падіння доходів, значному майновому та соціальному розшаруванню населення.

Згідно 3 дослідженням Київського міжнародного інституту соціології, що проводилося наприкінці травня 2017 року, «44\% українців від 18 до 29 років не планували взагалі кудись виїжджати 3 метою подорожей та відпочинку. За кордон планували подорожувати лише 4\% молодих людей. Також дуже великий відсоток молодих людей взагалі ніколи не виїжджали за межі України. А серед тих, хто виїжджає - більшість, на жаль, не 3 метою подорожей, а для працевлаштування» [1].

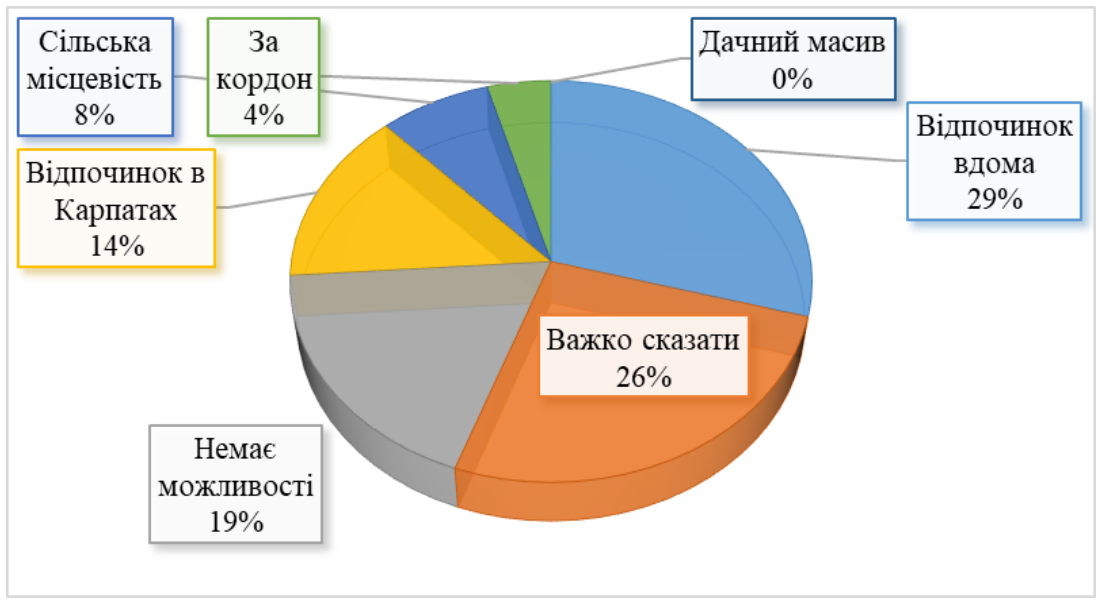

Рис. 1. Опитування щодо відпочинку молодих українців 
Основні причини ситуації слабкої туристичної активності української молоді: низький рівень соціально-економічного забезпечення молоді, нестача сформованого для української молоді туристичного продукту та інформації про нього, відсутність культури подорожування, яка формується 3 дитинства» [8].

Отже, можна стверджувати, що станом на сьогодні сучасне українське суспільство потребує розвитку саме соціального туризму, адже як вважають фахівці це дозволило би залучити до туристських подорожей мільйони українців, відкрило б широкі можливості оздоровлення, пізнання, залучення до культурних цінностей засобами туризму, сприяло би переорієнтації більшості населення на здоровий спосіб життя. Все це матиме позитивний вплив на соціально-економічний розвиток країни.

\section{Література:} https://www.radiosvoboda.org/a/24273633.html.

2. Електронний ресурс. URL: https://tourlib.net/statti_ukr/aleksandrova6.htm.

3. Колотуха О.В. Соціальний туризм в Україні: проблеми та перспективи розвитку. URL: http://dspace.nbuv.gov.ua/bitstream/handle/123456789/35500/39Kolotyha.pdf.

4. Задорожна К.І. Соціальний туризм у системі туристичної галузі: концептуалізація та інтеграція / К.I. Задорожна. URL: http://chtei-knteu.cv.ua/ herald/content/download/archive/2016/v2/NV-2016-v2_4.pdf.

5. Закон України про внесення змін до Закону України «Про туризм». Відомості Верховної ради України. 2004. № 13. Ст. 180.

6. Шанаурина Ю.В. Правовое обеспечение социально-культурного сервиса в туризме: учеб. Пособие. Москва : Флинта, 2013. 239 с.

7. Haukeland J. Non-travellers: the flip side of motivation. Annals of Tourism Research. 1990. Vol. 17. Issue 2. P. 172-184.

8. Manshina N. The main priorities and reasons for health resorts choice. Proc. of the 2nd European Congress on Health Tourism April 1-3 2009. Hungary. P. 76. 